\title{
Bioprinting's Introduction within the Context of the Convention on the Rights of Persons with Disabilities and Malaysia's Persons with Disabilities Act 2008 through the Right to Science
}

\author{
Marina Abdul Majid \\ Research Center for History, Politics and International Affairs, National University of Malaysia (UKM), \\ Selangor 43600, Malaysia; marina76@ukm.edu.my
}

Received: 7 April 2020; Accepted: 29 May 2020; Published: 30 May 2020

\begin{abstract}
Advances in bioprinting have enabled scientists to develop tissue and organs for the formation of artificial ears and noses, the treatment of injured joints because of arthritis, and the provision of medical care to people with disabilities. Malaysia's disabled population can benefit from bioprinting because the United Nations Convention on the Rights of Persons with Disabilities (CRPD) and Malaysia's Persons with Disabilities Act 2008 (PDA 2008) both include an indirect right to science expressed through the promotion of research and development (R\&D), technology transfer, and new technologies. This qualitative study aims to identify relevant provisions within the CRPD and PDA 2008 that could support bioprinting research. This study utilises a multidisciplinary approach that combines biomedicine, law, and the social sciences. It analyses the travaux préparatoires of CRPD negotiations, the CRPD, the PDA 2008, and related documents for clues that negotiators once considered as the right to science. The results show that the travaux préparatoires of CRPD negotiations refer to biomedicine, while Article 4(1) (g)-(h) of the CRPD and Articles 9(1) (k) and 33(3) of the PDA 2008 refer to R\&D, new technologies, and technology transfer, all of which indirectly imply the right to science and enable the introduction of bioprinting.
\end{abstract}

Keywords: Persons with Disabilities Act 2008 (PDA 2008); bioprinting; Convention on the Rights of Persons with Disabilities (CRPD); right to science

\section{Introduction}

The Fourth Industrial Revolution (IR 4.0) has introduced many breakthrough technologies that may have a profound impact on society. One of those technologies is bioprinting, defined as "the use of computer-aided transfer processes for patterning and assembling living and non-living materials with a prescribed two-dimensional (2D) or three-dimensional (3D) organisation in order to produce bio-engineered structures serving in regenerative medicine and in pharmacokinetic and basic cell biology studies" [1] (p. 1). The current state of bioprinting has enabled artificial skin and cartilage to be produced to replace a broken nose, to create an outer ear, and to repair an injured knee [2]. Besides these uses, bioprinting can generate original tissue, and in the future, scientists anticipate that this technology has the potential, at some point, to produce a complete and functional human heart and kidneys [3]. This indicates that bioprinting, a subset of biomedicine, will revolutionise the field of medicine in terms of the treatment of patients who are affected by diseases, injured in accidents, suffer from deformities or whose health has declined over time due to age. Scientists' quest for knowledge and exploration has enabled profound breakthroughs in bioprinting.

The aim of this study is to identify relevant provisions within the United Nations (UN) Convention on the Rights of Persons with Disabilities (CRPD) [4] and Malaysia's Persons with Disabilities Act 2008 
(PDA 2008) [5] that potentially support new technology such as bioprinting. Bioprinting holds the promise of reducing the hardship of those suffering from congenital, accident-based, and age-related physical disabilities. In order to support the use of such technology, the two documents to be analysed need to contain provisions that infer the right to science, research and development (R\&D), and the term technologies.

\section{Literature Review}

On 27 and 28 January 2014, the American Association for the Advancement of Science (AAAS) held its biannual meeting with the theme "Disability Rights and Accessing the Benefits of Scientific Progress and Its Applications" and highlighted the importance of the CRPD [6]. During this meeting, the crucial role of science in improving accessibility for, communicating with, and creating assistive technology for individuals with disabilities served as a primary topic [6]. While this meeting discussed the right to science in connection with people with disabilities, no effort was made to identify the relevant provisions within the CRPD that would promote the right to science or scientific progress in this area. Prior to this, Wolbring [7] (p. 196) had highlighted that certain statements within the CRPD, such as those contained within Article 4(1) (g)-(h), do refer to science and technology; these statements require states to provide therapeutic, enhancement-enabling, and assistive devices to people with disabilities. Cascio, Weiss, and Racine [8] (p. 4) pinpointed that the CRPD's obligation to promote research and new technologies implies a right to science, although these authors did not refer to any specific provision in the CRPD. Bryden and Gran [9] have also highlighted that Article 15 of the International Covenant on Economic, Social and Cultural Rights (ICESCR) [10] is a provision that promotes the right to technology and specialised services for those with disabilities, but, like Cascio, Weiss and Racine, they do not identify the relevant provisions in the CRPD. Given this scenario, this study seeks to investigate whether Article 4(1) (g)-(h) in the CRPD [4] promotes, with certainty, the right to science or scientific progress, as the scholarly literature has claimed. If it is true that Article 4(1) (g)-(h) of the CRPD [4] promotes this right to science, this study will compare the relevant text to that of Article 15 of the ICESCR [10], as this provision refers directly to the right to science and the United Nations Human Rights Council has interpreted this right as it applies to state obligations [11].

If the right to science is embedded within the CRPD, this right should refer to R\&D and the promotion and transfer of new technologies. An analysis of the provisions will permit this study to investigate if new technologies could include the introduction of bioprinting for the medical betterment of those with disabilities. Abegaz [12] has highlighted how 3D printing could aid the African continent to achieve the right to health in the production of prosthetics, implants, tissues, and organs. However, $3 \mathrm{D}$ printing and bioprinting are not identical; Abegaz fails to explain that the main difference between the two is that $3 \mathrm{D}$ printing can utilise plastics and metals to print external products for the human body, while bioprinting uses a bioink for printing. Abegaz [12] briefly refers to the right to health in the CRPD, but he does not identify any specific provision referring to the right to science, much less to the role of 3D printing and bioprinting in developing prosthetics and organs for those with disabilities [13-15]. This study thus provides an overdue analysis of the potentially relevant provisions in the CRPD that promote the right to science, $R \& D$, new technologies and their link with bioprinting.

Because this study focuses on people with disabilities in Malaysia, an examination of the PDA 2008 is critical; this act may contain provisions regarding the right to science, namely in terms of promoting R\&D and new technologies, and this may complement the provisions in the CRPD. Tah [16], Islam [17], and Tah and Mokhtar [18] have referred to Article 30 of the PDA 2008, which covers the right of those with disabilities to information and communications technology (ICT), as evidence that this piece of Malaysian legislation does cover technology availability and accessibility for this disenfranchised group. However, this provision is specific to ICT, and additional investigation of the PDA 2008 is necessary to identify additional provisions that promote other technologies in general; a blanket statement that encourages the use of new technology may apply to bioprinting and the benefits of this process for the disabled population of Malaysia. Furthermore, this study will try 
to identify if the PDA 2008 contains a provision to promote R\&D, as R\&D can spur technological breakthroughs. Previously, Talib, Sunar, and Mohamed [19] have highlighted how the technologies of IR 4.0, such as big data, machine learning, block chain, and the Internet of Things (IoT), can assist those with disabilities in Malaysia, allowing them to become independent technopreneurs by learning these technologies. Missing from Talib, Sunar, and Mohamed's list in IR 4.0, however, is bioprinting, which can equally provide medical assistance to those with disabilities. Therefore, this study aims to identify relevant provisions in the PDA 2008 that promote new technologies and R\&D, which will facilitate the introduction of bioprinting to assist people with disabilities in Malaysia.

\section{Methodology}

This is a qualitative study that is highly reliant on primary legal sources such as the CRPD and the PDA 2008, in addition to other primary resources including the travaux préparatoires, which give documented evidence of the CRPD negotiations from the United Nations Department of Economic and Social Affairs (UNDESA) and the United Nations General Assembly (UNGA) websites. These travaux préparatoires were examined for terms such as $\mathrm{R} \& \mathrm{D}$, new technologies, technology, technology transfer, and ICT. The presence of these keywords in these documents could suggest the intention of parties to negotiate a broad range of technology that would be covered by the terminology used. In addition to analysing the documents above, this study searched them for terms such as biotechnology and biomedicine, which could signify the forms of technology to which the countries involved in the negotiations for the CRPD wanted to refer. If the final CRPD contains any provision that reflects the encouragement of $R \& D$, technologies, and the transfer of new technologies, this signifies that the right to science is reflected in the CRPD, specifically in a context in which a new technology could be beneficial for those with disabilities. If the travaux préparatoires do contain such provisions, these provisions serve as an avenue by which to introduce bioprinting as a new technology of IR 4.0, along with ICT and assistive technology (AT), which are clearly mentioned in Article 4 of the CRPD [4].

This study drew upon the UNGA and United Nations Educational, Scientific and Cultural Organization (UNESCO) websites to obtain the documents necessary to decipher the meaning of the right to science or scientific progress; either definition aids in the interpretation of any provisions in the CRPD related to R\&D and new technologies. Moreover, this study also refers to certain case laws that have interpreted state responsibility with regard to the right to science. Additionally, this study also examines the Universal Declaration on Human Rights (UDHR) [20] and the International Covenant of Economic, Social and Cultural Rights (ICESCR) [10] to identify relevant provisions referring to the right to science, as any such provisions could parallel relevant text in the CRPD. Similarly, this study examines Malaysia's PDA 2008 to determine if any of its provisions contain terms related to R\&D and new technologies. The presence of pertinent terminology in the PDA 2008 may provide an opportunity for the introduction of bioprinting.

Because this study is highly reliant on treaties and the travaux préparatoires of the CRPD, the analysis that follows will utilise interpretivism to decipher the meaning of relevant provisions within the international agreements (CRPD and ICESCR) and soft law document (UDHR) in the context of the right to science. In this sense, this study concerns legal hermeneutics, which is "a science of interpretation concerning the application of legal rules from the foundations of philosophical hermeneutics" [21] (p. 4). The procedure for interpreting text in legal hermeneutics covers understanding, interpretation, and reference to both the legal text and context [21] (p. 4).

Furthermore, this study is multidisciplinary, combining law, the social sciences, and biomedicine. For this reason, this study adopts a socio-legal approach which, according to the United Kingdom's Economic and Social Research Council, encompasses a "wide-ranging and varied area of research activity" that enables a variety of methods and perspectives to be utilised [22] (p. 35).

A socio-legal approach is also used in this study because it employs research methods typical of the social sciences. This study undertakes textual analysis to interpret the provisions of international agreements and case laws, and content analysis entailing the grouping of relevant secondary literature 
into three themes: bioprinting medical applications, bioprinting research in Malaysia, and the scholarly literature written about the PDA 2008. The secondary literature, including books, journals, conference and working papers, newspapers, magazine articles, and online publications, is integral to this study. Journal articles and conference and working papers were downloaded from Google Scholar and Researchgate. A summary of the methodology used in this study is presented in Figure 1.

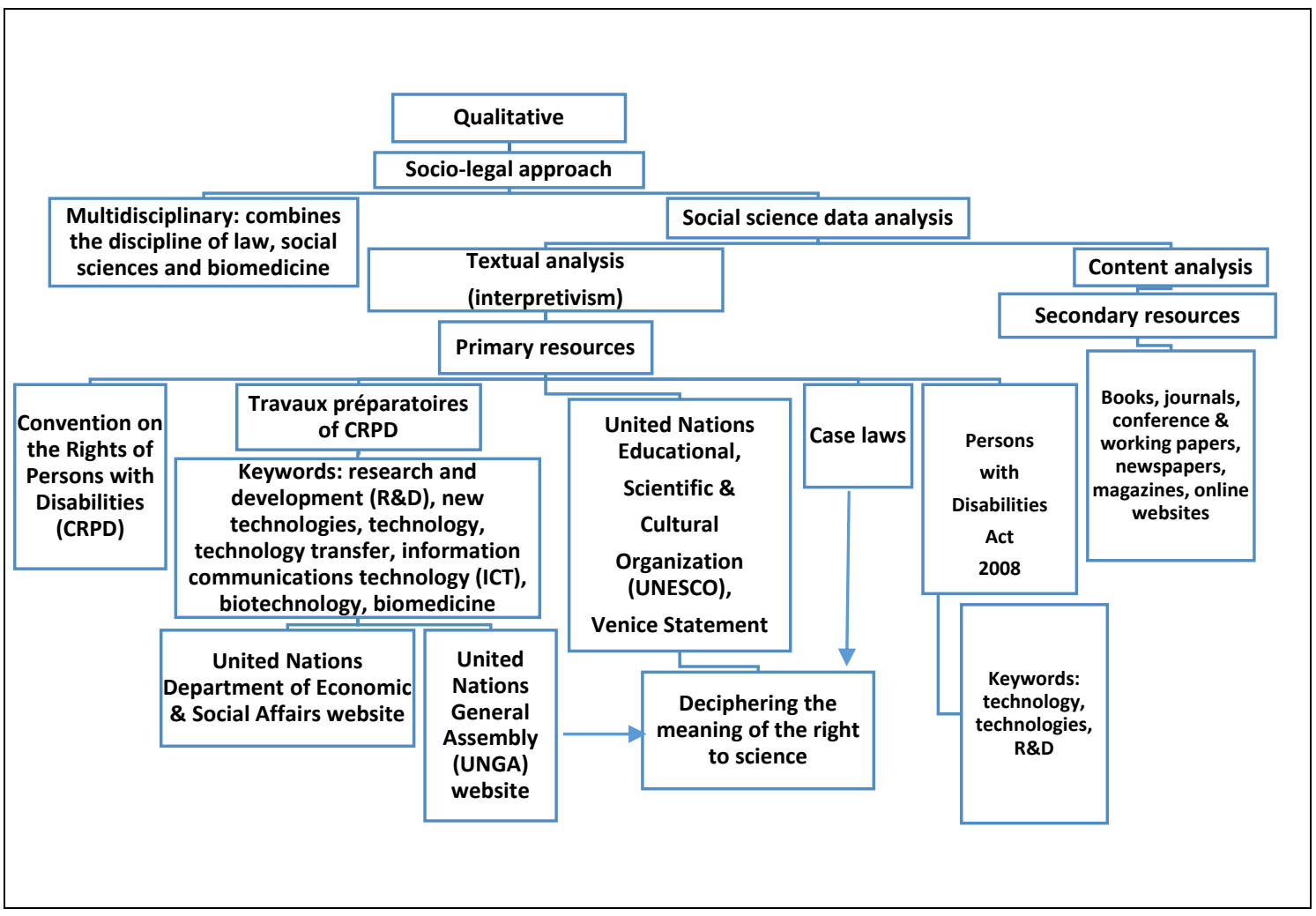

Figure 1. A summary of the methodology used in this study.

\section{Overview of the United Nations Convention on the Rights of Persons with Disabilities (CRPD) and the Scope of Disability}

The CRPD was first adopted on 13 December 2006 at the UN headquarters in New York [23]. The CRPD currently has 163 signatory states and 181 ratifications/accessions [24]. The CRPD came into effect on 3 May 2008 [23].

Article 1 of the CRPD states the intention of this international agreement:

"The purpose of the present Convention is to promote, protect and ensure the full and equal enjoyment of all human rights and fundamental freedoms by all persons with disabilities, and to promote respect

for their inherent dignity." [4]

The provisions of the CRPD are quite extensive, covering issues such as accessibility; personal mobility; employment; the right to leisure and sports; participation in political life, education, health, habilitation, and rehabilitation; access to ICT and AT; the hardships that women and children with disabilities face; and various other matters (refer to Articles 4-22 regarding the scope of issues covered under the CRPD) [4].

The CRPD is a human rights agreement exclusive to those with disabilities. The CRPD shifts the understanding of persons with disabilities from being objects deserving of charity and requiring medical treatment and social protection to individuals with inherent human rights who are capable of claiming these rights. This international agreement also permits individuals with disabilities to take active roles in society and make their own life decisions based on free informed consent (Article 25 
concerning health and consent and Article 15 on cruel, inhuman, and degrading treatment) [4]. Those with disabilities must not be subject to discrimination (Article 5 of CRPD), and the convention states that parties to the CRPD are under general obligations to provide those with disabilities with certain goods, services, facilities, and devices as stipulated in Article 4 [4]. The CRPD also stresses the need to make accommodations for those with disabilities on public transportation and in terms of facilities, education, and access to ICT (see Articles 9 and 24 of the CRPD) [4]. If the rights of those with disabilities are violated, there is also room for redress and access to justice (Articles 12-13 of the CRPD) [4]. Figure 2, as indicated below, summarises the various issues and related provisions addressed by the CRPD as already mentioned. The above, which is by no means exhaustive, provides a brief overview of the CRPD and its contents. However, extensive elaboration on each provision in the CRPD is beyond the scope of this study; the focus is to identify any relevant provisions that might support the introduction of bioprinting for the betterment of people with disabilities.

Within the CRPD, the final text in the convention neglects to provide a definition of "disability". The chairman who was tasked with overseeing the drafting of the CRPD, in a letter on 7 October 2005, stated the following:

"Views are divided as to whether it is necessary to define "Disability" and "Persons with disabilities."

I tend to think that we don't, as this will be very difficult, and there is a risk that we will unintentionally exclude someone." [25] (p. 3)

Based on the chairman's statement, the decision to avoid a definition of disability was attributed to concerns about including certain groups of individuals at the expense of others. Moreover, the understanding of disability may change over time, as the concept of disability is a social construct and in the future, it may include people who were previously excluded [26] (p. 551).

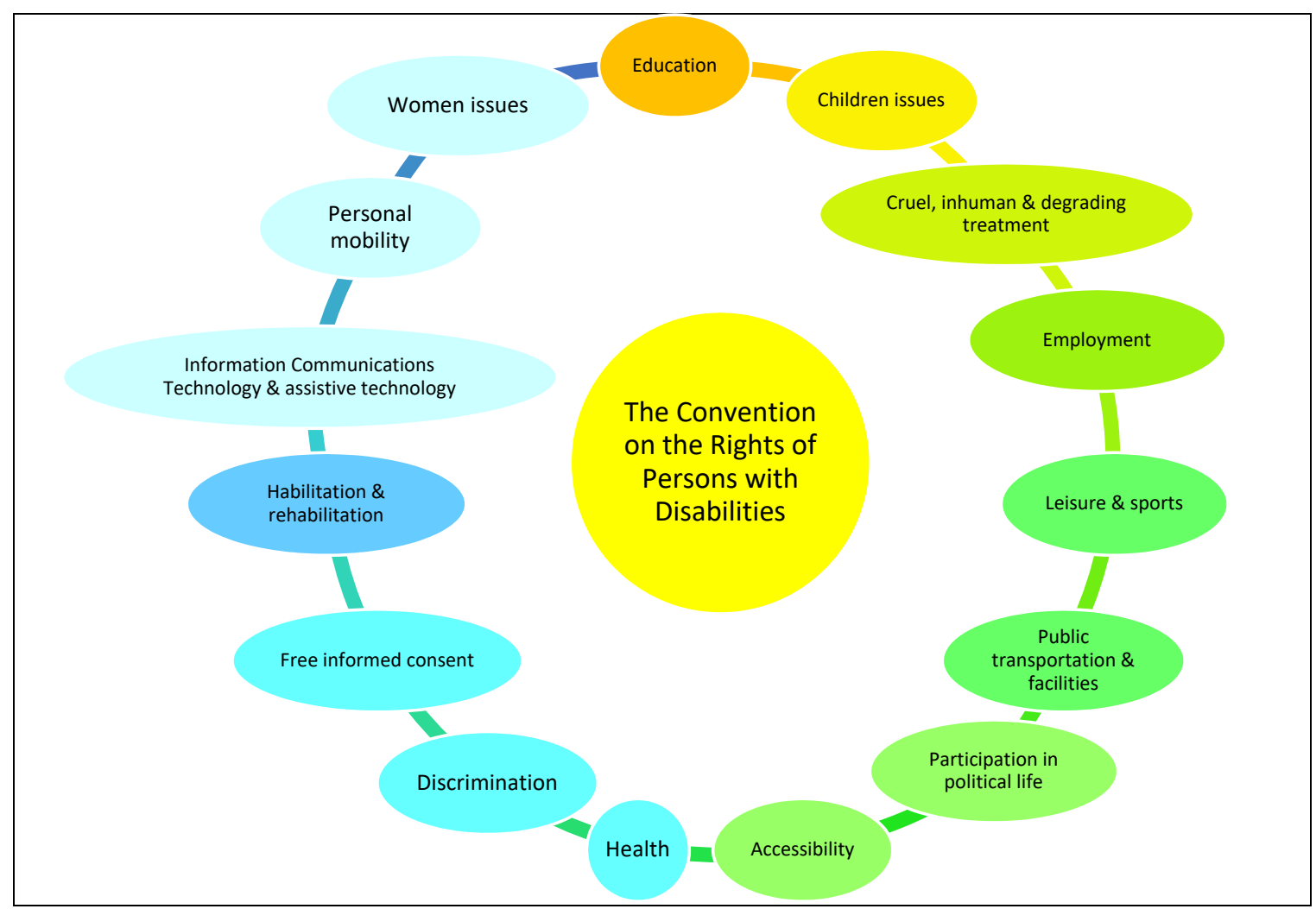

Figure 2. Some of the pertinent issues covered by the Convention on the Rights of Persons with Disabilities.

Additionally, another justification for excluding a definition of disability was based on the concern that a definition would undermine the rights-based approach to disability, which stresses the 
eradication of unequal treatment among those with disabilities [26] (p. 551). By declining to provide a definition on disability, however, the convention allows individual states to include certain conditions as disabilities while others may be excluded. There is thus no uniform, worldwide standard by which to classify who does and who does not have a disability, as states are able to adopt divergent policies and laws [27]. At the seventh session concerning the draft of the CRPD, the chair did attempt to provide a definition of disability to be included in the CRPD, but state representatives could not reach a consensus on a suitable definition [27]. Therefore, a revision was made to Article 1 of the CRPD in relation to the purpose of providing an understanding of a disabled person within this agreement. Article 1 of the CRPD now reads:

"Persons with disabilities include those who have long-term physical, mental, intellectual or sensory impairments which in interaction with various barriers may hinder their full and effective participation in society on an equal basis with others." [4]

The above statement, which describes individuals with disabilities, provides flexibility in that it can be applied to people with deformities and the elderly, for example, because the phrasing does not make any distinctions between people according to age. Article 25(b) of the CRPD, which concerns health services for persons with disabilities, is extended to older persons [4]. The same is true for Article 28(2) (b) on the right of access to social protection and poverty reduction programmes and Article 13(1) on access to justice, which encompasses "age-appropriate accommodations" that extend to the elderly [4]. Freedom from exploitation, violence, and abuse in Article 16(2) of the CRPD also refers to "age-sensitive assistance", implying that the stipulations in this article could cater to the needs of the elderly [4]. Other relevant provisions that could apply to elderly people include Article 9 on accessibility, Article 19 on independent living, Article 20 on personal inability, and Article 26 on habilitation and rehabilitation [4]. This clearly shows that the CRPD's scope was meant to cover individuals with physical deformities and include the elderly.

The analysis of the CRPD in the following section will identify any relevant provisions that encompass R\&D, technologies, or science that could facilitate the introduction of bioprinting for medical applications for those with disabilities, which will cover individuals who are disabled because of an accident, deformed, or elderly.

\section{Results of the Study}

Upon examination, it can be seen that the CRPD does indeed contain provisions that indirectly reflect the right to science. Below are the findings from the CRPD, which first identifies the relevant provisions and then elaborates upon the form of rights accorded to those with disabilities and upon the responsibilities entrusted to states. The following subsections will subsequently also expand on the medical benefits of bioprinting for those with disabilities, on the state of bioprinting in Malaysia, a description of the disabled population in Malaysia and the benefits that bioprinting could bring them, as well as the presence of the right to science within Malaysia's PDA 2008.

\subsection{Provisions on Research and Development (RED) and New Technologies to Support the Right to Science and} Bioprinting within the Convention on the Rights of Persons with Disabilities (CRPD)

This section will examine various travaux préparatoires in the past negotiations of the CRPD to trace whether any states, international organisations, or non-governmental organisations (NGOs) ever raised the possibility of including $R \& D$, new technologies, or the usefulness of science in the draft text of the CRPD. If so, then it was clearly the intention of the parties to the negotiations that R\&D and new technologies could be extended to the creation of goods, services, and devices useful for those with disabilities.

The initiative to start drafting the CRPD began with a few regional initiatives in Southeast Asia and Latin America. At the Américas Regional Seminar and Workshop on Norms and Standards Related to the Rights of Persons with Disabilities and Development, which was held in Quito, 
Ecuador, on 9-11 April 2003, attendees proposed that a convention on disability should include a provision on "accessibility, physical environment and communication technology/other technologies 'alternatives'" [28] (p. 14). Later that year, during the Regional Workshop towards a Comprehensive and Integral International Convention on Protection and Promotion of the Rights and Dignity of Persons with Disabilities, held on 14-17 October 2003 in Bangkok, Thailand, the Bangkok Draft: Proposed Elements of a Comprehensive and Integral International Convention to Promote and Protect the Rights and Dignity of Persons with Disabilities (also called the Bangkok Draft) similarly proposed Article 16(2) on accessibility, which included a crucial statement: "States Parties should encourage the research, development and promotion of new technologies to assist in the promotion of persons with disabilities in all aspects of life" [29] (p. 13). It can be observed from both regional initiatives that proposals were made to include "other technologies", but the Southeast Asian initiative was more specific in indicating that R\&D should lead to new technologies for the good of those with disabilities. Furthermore, the Bangkok Draft did not specify the form of technology; this detail was left open-ended, perhaps to include any kind of technology that may develop over time.

In the Compilation of Proposals for Elements of a Convention, dated 15 January 2004, China proposed a provision in the form of Article 5: those with disabilities should have an "accessible physical environment, information and communication, and shall take measures to ensure their freedom, independence and full participation in all kinds of social life, especially: $[\ldots$ a $]$ dvance the research, development and promotion of new technologies suitable for persons with disabilities" [30] (p. 115). Mexico added to the compilation of proposals, presenting Article 13(e), which covered the right to health and rehabilitation of those with disabilities:

"States Parties shall [ ... a]dopt all measures necessary to guarantee that the medical, rehabilitation, and assistance services provided to persons with disabilities include [ ... m]odern medical assistance and treatment that include the use of new technologies." [30] (p. 128)

Likewise, Venezuela also proposed a provision in the form of Article 10, which concerned health care and rehabilitation services, and this article required state parties to adopt all measures guaranteeing medical services, including "[d]ignified, appropriate and modern medical assistance and treatment that includes the use of new technologies" [30] (p. 131). The Compilation of Proposals also included a text by the Chairman of the Ad Hoc Committee in the form of Article 21, which addressed accessibility by compelling state parties to "encourage the research, development and promotion of new technologies to assist in the promotion of persons with disabilities in all aspects of life" [30] (p. 112). Notably, the proposal from China was specific in proposing new technology in the form of ICT, while the Mexican and Venezuelan proposals referred to new technologies with regard to the right to health and rehabilitation.

In both the Report of the Working Group to the Ad Hoc Committee, dated January 2004, and the Report of the Third Session of the Ad Hoc Committee on a Comprehensive and Integral International Convention on the Protection and Promotion of the Rights and Dignity of Persons with Disabilities, dated June 2004, Chile proposed that the then-draft Article 21(f), covering the right to health and rehabilitation, should oblige state parties to "[e]ncourage research and development, dissemination and application of new knowledge and technologies that benefit persons with disabilities" in specific reference to the fields of biomedical, genetic, and scientific research [31] (p. 52). Based on the history of the negotiated CRPD, there was clearly an attempt made to clarify the scope of new technologies and to mention specific technologies, such as biomedicine and genetic research, in the CRPD's application of health and rehabilitation. If the intention was that new technologies should include biomedicine, this scope could easily cover bioprinting, which is a subarea of the broader field of biomedicine. It is also apparent, by proposing that biomedicine be applied to the right to health and rehabilitation, that any revolutionary technology of the future, such as bioprinting, could be used to treat ill patients with disabilities, those who have suffered an injury from an accident, and indisposed elderly people. By linking health with new technologies, this also implies that any health treatment is dependent on the right to scientific progress. 
By the time of the next Report of the Ad Hoc Committee on a Comprehensive and Integral International Convention on the Protection and Promotion of the Rights and Dignity of Persons with Disabilities, at the seventh session in February 2006, the references to new technologies in the context of accessibility, the right to health and rehabilitation, and in the draft text of the CRPD, were removed [32]. Instead, the draft text for the CRPD under the ambit of general obligations in Article 4(1) (f) proposed the following:

"[t]o undertake or promote the research, developments, availability and use of: (ii) New technologies, including information and communication technologies, mobility aids, devices, assistive technologies, suitable for persons with disabilities, giving priority to technologies at an affordable cost." [32] (p. 10)

Article 4(1) (g) on general obligations in the draft text of the CRPD also refers to new technologies but in the context of disabled people having accessible information about these technologies. Specifically, Article 4(1) (g) of the then-draft text of the CRPD mentions this need:

"(g) To provide accessible information to persons with disabilities about mobility aids, devices and assistive technologies, including new technologies, as well as other forms of assistance, support services and facilities." [32] (p. 10)

It would seem that the shift towards new technologies as a general obligation, rather than being connected to the right to health and rehabilitation and accessibility, as discussed before this, has certain implications. By considering new technologies as a general obligation, this choice implies that the technology can apply to any situation and is not merely restricted to health and accessibility. The new technologies could apply, for instance, to educational services for those with disabilities.

In the final CRPD, the terms "new technologies" and "R\&D" appear as Article 4(1) (g) and 4(1) (h) concerning general obligations. The final Article 4(1) (g) of the CRPD is quoted below:

"To undertake or promote research and development of, and to promote the availability and use of new technologies, including information and communications technologies, mobility aids, devices and assistive technologies, suitable for persons with disabilities, giving priority to technologies at an affordable cost." [4]

Article 4(1) (h) of the CRPD, in its final form, reads as follows:

"To provide accessible information to persons with disabilities about mobility aids, devise and assistive technologies, including new technologies, as well as other forms of assistance, support services and facilities." [4]

Article 4(1) (g) of the CRPD seems to place an obligation on state parties to ensure that scientists and engineers undertake scientific research for those with disabilities in the hope of developing new technology for the disabled population and making the technology available to them. On the other hand, Article 4(1) (h) of the CRPD makes it an obligation for state parties to inform and make available relevant information about new technologies to people with disabilities so that they are informed about the technology's potential for the betterment of health. Notably, "new technologies" is not defined in Article 2 of the CRPD [4]. New technologies would seem a deliberately open-ended term, as this ambiguity could accommodate any future form of technology that could be used to benefit people with disabilities, covering any situation. While Article 4(1) (g) of the CRPD may refer to different forms of technology with the term "new technologies", there is an emphasis on and priority given to ICT; the phrase "including information and communication technologies" stresses this particular technology's usefulness to those with disabilities [4].

Based on the travaux préparatoires of the CRPD, it can be presumed that parties to the negotiations intended, from the outset, for scientific research to be conducted for the generation of new technologies to be used by those with disabilities; the use of the term R\&D is key evidence of this intention. From a proposal to cover technologies in general, the CRPD evolved to include a special emphasis on ICT, 
as contained in Article 4(1) (g) of the CRPD. Whenever scholars have elaborated on Article 4(1) (g)-(h) of the CRPD, emphasis has been placed on AT and ICT for people with disabilities but at the expense of other possible technologies [7,33]. The analysis in this section has shown that Article 4(1) (g)-(h) of the CRPD, in particular, may encompass bioprinting because Chile once recommended the inclusion of biomedicine among the specific forms of applicable technologies [31] (p. 52). In this context, other sections in this study will explore the benefits of bioprinting for disabled persons in general and in Malaysia, with specific reference to those who have physical deformities or are elderly. First, though, the next section will investigate the responsibilities entrusted to state parties in enforcing Article 4(1) (g)-(h) of the CRPD, which indirectly implies a right to science or scientific progress. Cascio, Weiss, and Racine [8] (p. 4), for instance, mention that the CRPD promotes research; this implies the right to science, though the authors have not specifically identified which provisions of the CRPD are relevant. Based on the analysis conducted in this section, it is apparent that the CRPD indirectly relates to the right to science, but the next section provides further exploration of how this right should be enforced.

\subsection{Accorded Rights and Responsibilities with Regard to the Right to Science in the Convention on the Rights of} Persons with Disabilities (CRPD)

As indicated in the previous section, Article 4(1) (g)-(h) of the CRPD indirectly implies the right to science because the article stresses R\&D. If this implication is true, the obligations and actions required of the state and other parties to realise the right to science must be deciphered.

Provisions in two other international law documents already address the right to science: Article 27 of the UDHR [20] and Article 15(1) (b) of the ICESCR [10]. In 2012, the Human Rights Council appointed the Special Rapporteur, Farida Shaheed, to investigate the meaning of the right to enjoy the benefits of scientific progress and its applications, and Shaheed's investigation led to a report [11]. The right to science was regarded as a "means to advance the realisation of other human rights" [11] (p. 3). This is true, as Scanlon, MacNaughton, and Sprague [34], in their elaboration on drugs to combat human immunodeficiency virus/acquired immunodeficiency syndrome (HIV/AIDS), have stressed that the right to science is strongly linked to the right to health. Without advancement in knowledge and technological progress in drug development, new drugs cannot be created to treat HIV/AIDS patients who suffer from acute health symptoms with a weakened immune system. The right to science must be understood as an example of people's ability to aspire, that is, "to conceive a better future that is not only desirable but attainable" [11] (p. 7).

The right to enjoy the benefits of scientific progress and its applications also refers to non-discrimination and the involvement of marginalised communities. Shaheed's report on the right to scientific progress underlines "the need to ensure that scientific research is conducted on key issues, including for the most vulnerable" [11] (p. 12). Prior to this, the Venice Statement on the Right to Enjoy the Benefits of Scientific Progress and its Applications (hereafter the Venice Statement) indicated that one of the state's obligations is "to promote access to the benefits of science and its applications on a non-discriminatory basis including measures necessary to address the needs of disadvantaged and marginalised groups" [35] (p. 17). This excerpt is similar to Article 4(1) (g) of the CRPD, which stresses R\&D and promotes the availability of new technologies to those suffering from disabilities. These three sources imply that a state should ensure that any scientific research addresses concerns and develops products that are useful for disabled people, and that their needs should not be ignored. Because Article 27 of the UDHR [27] and Article 15(1) (b) of the ICESCR [10] cover the right to scientific progress, which Article 4(1) (g) of the CRPD implies indirectly, the similarities among these international documents underscore the essential role that R\&D ultimately plays in aiding people with disabilities.

The CRPD and the interpretation of the right to scientific progress within the UDHR and ICESCR all refer to access to ICT as key to empowering those with disabilities. Article 4(1) (g) of the CRPD places particular emphasis on ICT with the phrase "including ICT", because this is an essential technology that spurs the development of other technologies [4]. Because the right to scientific 
progress has been interpreted to include access to ICT and applies to the UDHR and ICESCR, these international documents are evidently similar in content to the CRPD. The Special Rapporteur's final recommendation concerning the right to scientific progress explicitly states the following:

"States ensure freedom of access to the Internet, promote open access to scientific knowledge and information on the Internet, and take measures to enhance access to computers and Internet connectivity." [11] (p. 20)

Thus, within the three international documents, having access to ICT is considered to be of utmost importance in realising the right to scientific progress.

Furthermore, Article 4(1) (h) of the CRPD is identical to the UDHR and ICESCR in its perspective on the right to scientific progress; this provision in the CRPD stresses the need to provide accessible information about new technologies that can improve the quality of life for those with disabilities [4]. As part of the normative content concerning state obligations, the Venice Statement [35] (p. 16) advocates the "[c]reation of an enabling and participatory environment [ ... ] including freedom of opinion and expression, to seek, receive and impart information." The Special Rapporteur, in her interpretation of the right to scientific progress, has made it clear that the right to scientific progress is "understood as a right to be introduced to and informed about main scientific discoveries and their applications" [11] (p. 9). Being informed about new scientific discoveries or new technologies such as bioprinting will enable disabled people to make informed decisions about the technologies that have the potential to contribute to the creation of products and devices that can help them to manage their impairments. According to the World Health Organization (WHO), medical devices could include implants "intended by the manufacturer to be used, alone or in combination for human beings, for one or more of the specific medical purpose(s) of: (i) [ ... ] treatment of disease; (ii) [ . . ] treatment, alleviation of or compensation for an injury; (iii) [ ... ] replacement, modification, or support of the anatomy or of a physiological process [... ]" [36] (p. 1). Based on the WHO's definition of a "medical device", any bioprinted organ, tissue, or bone that can be transplanted into humans would qualify as an implant for the purpose of treating diseases, treating an injury, or functioning as a replacement body part.

For the purposes of illustration, the Inter-American Court of Human Rights decided that the denial of advancements of in vitro fertilisation (IVF) techniques for the reproductive rights of Costa Rican women was a violation of the right to science, as indicated in the following statement:

"The right to have access to scientific progress in order to exercise reproductive autonomy and the possibility to found a family gives rise to the right to have access to the best health care services in assisted reproduction techniques, and, consequently, the prohibition of disproportionate and unnecessary restrictions, de iure or de facto, to exercise the reproductive decisions that correspond to each individual." [37] (p. 46, paragraph 150)

The above case details the plight of a group of marginalised Costa Rican women who should have been entitled to IVF as part of the progress in reproductive science. However, the health authorities in Costa Rica denied these women this right. The moral of this case is that a state has an obligation to ensure that its citizens have access to a particular technology for the well-being of their health as part of the right to science.

In López, Glenda y otros c. Instituto Venezolano de los Seguros Sociales (IVSS) s/acción de amparo [38], a group of people who were living with HIV/AIDS filed a case against the Instituto Venezolano de los Seguros Sociales (IVSS) in Venezuela for failing to ensure a consistent supply of triple-therapy drugs and other drugs that the plaintiffs needed and for refusing to cover the expenses of all necessary medical tests. The court indicated that these unfortunate people suffering from HIV/AIDS had the right to health and the right to life and that the authorities' inaction constituted "a breach [of] the right to the benefits of scientific and technological progress" [38] (p. 16). This case illustrates that national authorities must provide necessary drugs and medical care, or they will violate the victims' right to science in benefiting from advances in medical technology. 
Additionally, the right to scientific progress also entails the need for states to ensure that the benefits of science are physically available and economically affordable [11] (p. 10). Article 4(1) of the CRPD, similar to the provision in Article 27 of the UDHR and Article 15(1) (b) of the ICESCR [4,10,20], also asserts that new technologies must be made available at a reasonable price. If a private organisation develops a scientific product and sells the product at an excessively high price, a state should intervene and reduce the cost of the product to benefit marginalised groups. The Venice Statement states the following:

"The relationship between human rights and science is further complicated by the fact that private and non-state actors are increasingly the principal producers of scientific progress and technological advances. It is the responsibility of States to ensure that all relevant interests are balanced, in the advance of scientific progress, in accordance with human rights." [35] (p. 14)

Therefore, if a state has to introduce a policy or piece of legislation in favour of those disfranchised in society, as they may not be able to afford a particular new technology, a product, or device, the state must take all necessary action to promote the equality of all humans. Moreover, the Venice Statement reiterates that states have the duty "to adopt a legal and policy framework and to establish institutions to promote the development and diffusion of science and technology in a manner consistent with the fundamental human rights" [35] (p. 17).

In addition, the interpretation of the right to scientific progress notably asserts that "new technological applicants should entail a participatory process" [11] (p. 13). This statement is crucial for those with disabilities; their opinions about the development of products and devices for their use are deemed essential. The Special Rapporteur, in her final recommendation concerning the right to scientific progress, stressed the following:

"States ensure the participation of individuals, communities and peoples in decision-making relating to science in order to [ ... ] provide opportunities for all to make informed decision after considering both the possible improvements and potentially harmful side effects or dangerous usages of scientific advances." [11] (p. 20)

The right to scientific progress also entails the equitable showing of benefits and transfer of technologies [11] (p. 18). Likewise, the Venice Statement similarly mentions that states need "to take measures to encourage and strengthen international cooperation and assistance in science and technology to the benefit of all people and to comply in this regard with the States' obligations under international law" [35] (p. 17). In enabling this effort, industrialised states should provide "direct aid, financial and material, as well as the development of international collaborative models of research and development for the benefits of developing countries and their populations" [11] (p. 18). Moreover, the Special Rapporteur, in emphasising the transfer of technologies in the context of the right to scientific progress within the UDHR and the ICESCR, asserted the following:

"Developing countries should prioritise the development, importation and dissemination of simple and inexpensive technologies that can improve the life of marginalised populations. Industrialised states should comply with their international legal obligations by means of direct aid and the development of international collaborative models of research and development." [11] (p. 20)

The above interpretation of the right to scientific progress with regard to people with disabilities would require states to acquire low-cost technology that can ease the lives of those with disabilities. However, the above statement may seem discriminatory; developing countries are not entitled to higher-cost technology, such as bioprinting, which can be medically beneficial for people with disabilities who need tissue or complex organ replacement. The more affluent countries, on their part, must facilitate technology transfer through R\&D collaboration.

Most noteworthy, the CRPD includes a provision on international collaboration, Article 32(1) (b)-(c) [4], which has similar implications for the right to scientific progress in the UDHR and the 
ICESCR. Article 32(1) (b) of the CRPD emphasises capacity building by sharing information, experiences, training programmes, and best practices [4]. Article 32(1) (c) of the CRPD seeks to facilitate cooperation in research and access to scientific and technical knowledge [4].

Thus, the provisions within the CRPD, covering R\&D and new technologies, indirectly address the right to science. As the analysis has shown in this section, most of the provisions in the CRPD covering R\&D, new technologies, and ICT accessibility could be correctly interpreted as evoking the right to scientific progress, which is also apparent in Article 27 of the UDHR and Article 15(1) (b) of the ICESCR. The similarities between the CRPD, the UDHR and ICESCR in addressing the right to science are summarised in Table 1 below.

Table 1. Similarities in terms of the right to science between the Convention on the Rights of Persons with Disabilities (CRPD), the Universal Declaration on Human Rights (UDHR) and the International Covenant on Economic, Social and Cultural Rights (ICESCR).

\begin{tabular}{|c|c|}
\hline CRPD & $\begin{array}{l}\text { Interpretation of the Right to Science in Art. } 27 \text { of } \\
\text { the UDHR and Art. 15(1) (b) of the ICESCR }\end{array}$ \\
\hline $\begin{array}{c}\text { Art. } 4(1)(\mathrm{g}) \text { of the CRPD stresses that research and } \\
\text { development (R\&D) be conducted and new technologies } \\
\text { be promoted for persons with disabilities who are } \\
\text { marginalised. }\end{array}$ & $\begin{array}{l}\text { The relevant Articles address the need for scientific } \\
\text { research to be conducted for marginalised } \\
\text { communities without discrimination. }\end{array}$ \\
\hline $\begin{array}{c}\text { Art. 4(1) (g) of the CRPD refers to Information } \\
\text { Communications Technology (ICT) for the benefit } \\
\text { of the disabled. }\end{array}$ & $\begin{array}{l}\text { The right to science includes ensuring freedom of } \\
\text { access, the promotion of information on the internet } \\
\text { and its connectivity. }\end{array}$ \\
\hline $\begin{array}{l}\text { Art. } 4(1)(\mathrm{h}) \text { of the CRPD stresses the need for accessible } \\
\text { information to improve the life of disabled people. }\end{array}$ & $\begin{array}{l}\text { The right to science has been interpreted as including } \\
\text { the right to be informed of new scientific discoveries } \\
\text { and their applications in order to improve the life of } \\
\text { marginalised communities. }\end{array}$ \\
\hline $\begin{array}{l}\text { Art } 4(1)(g) \text { of the CRPD stresses that new technologies } \\
\text { must be made available at an affordable price. }\end{array}$ & $\begin{array}{l}\text { The right to science has also been interpreted as } \\
\text { meaning that new technologies must be made } \\
\text { available at an affordable price. }\end{array}$ \\
\hline $\begin{array}{l}\text { Art. } 32(1)(b)-(c) \text { of the CRPD emphasises international } \\
\text { collaboration which covers capacity building, namely in } \\
\text { the sharing of information, experiences, training } \\
\text { programmes and best practices, for the benefit of } \\
\text { disabled people. Cooperation in R\&D and access to } \\
\text { scientific knowledge are also stressed. }\end{array}$ & $\begin{array}{l}\text { The right to science has been understood to include } \\
\text { international cooperation and assistance in science } \\
\text { and technology which may cover direct aid, financial } \\
\text { and material assistance, and collaborative models of } \\
\text { R\&D for the benefit of developing countries. }\end{array}$ \\
\hline
\end{tabular}

\subsection{Bioprinting Medical Applications for the Benefit of Those with Disabilities}

In 2016, László Gábor Lovászy, a member of the UN Committee on the Rights of Persons with Disabilities, referred to 3D printing technology in a EuroScientist article as a new way of rehabilitating people with disabilities [39] (p. 3). However, the possibility that 3D printing and its subset, bioprinting, could transform the lives of those with disabilities warrants further exploration. This section will highlight some developments that have occurred in the area of bioprinting and that could leave lasting medical impacts on the lives of those with disabilities.

Bioprinting has enabled the creation of an artificial ear by generating cartilage using a patient's own cells; this use of autologous tissue allows transplants for children born with a congenital deformity known as microtia [3] (p. 571). Children with microtia experience hearing difficulties, suffer from impaired speech, and have underdevelopment of the external ear (pinna). University College London (UCL) has used a lightweight scaffold infused with bionutrients to induce tissue growth [3] (p. 573), and this artificially shaped ear, moulded according to the shape of the scaffolding, is then implanted in a patient's forearm to enable neovascularisation to occur. While subdermal, the tissue develops the necessary capillaries and cells to mimic a real ear over a period of several months. Once a full artificial ear has been formed, it is ready for transplant. This technique of creating artificial ears is now undergoing human trials in the UK and India, as microtia is a concern, especially in developing 
countries [3] (p. 573). This new method is revolutionary because the utilisation of a patient's own cells prevents any rejection of the artificial ear; prior to this, the replacement of an ear would require harvesting cartilage from the patient's ribcage, forcing the patient to undergo multiple operations.

In 2018, scientists and a medical team from Jiao Tong University, the National Tissue Engineering Research Centre of China, the Chinese Academy of Medical Sciences, Wei Fong Medical College, and Dalian University similarly created artificial ears for children suffering from microtia using bioprinting and stem cell regeneration [40]. A scan was taken of a patient's ear in 3D form, and then a resin model of this ear was printed based on digital images of the scan. The model was then used to cast a pair of moulds from clay and silicone that would hold the scaffolding created for the artificial ear. Each child's cells were then harvested from the microtic ears and evenly placed on the scaffolding to generate more cells with growth factors. After 12 weeks, the artificial ears were formed and subsequently transplanted into each patient. After two and a half years, it was found that most of the chondrocytes remained healthy and intact [41]. Not all cases of implantation were successful, however; there was one child whose ear produced less cartilage, while another child had a less aesthetically pleasing ear [41]. While human experimentation on testing the feasibility of bioprinted ears has only just begun, this technique holds promise for those suffering from microtia.

For those suffering from arthritis, bioprinting may also help to create living tissues that can be implanted into the human body to enable a damaged joint to heal itself [42]. Bioprinting may be a future solution for people suffering from painful arthritis affecting their joints near their fingers, toes, and knees, which may impair their mobility. As arthritis breaks down the rubbery cartilage found in joints, bioprinted tissue with stimulated stem cells implanted into a living joint would regenerate new cartilage to ease a patient's pain [42]. Thus, individuals who are disabled because of arthritis may benefit from bioprinting through the creation of living tissue.

As for individuals who have suffered from a broken nose because of an accident, bioprinting holds the key to the creation of an artificial nose. At the Swiss Federal Institute of Technology (ETH Zürich) in Zürich, Switzerland, scientists have developed a procedure for producing artificial noses using bioprinting [43]. A 3D scan is taken to obtain a digital image of a patient's nose while cartilage cells are harvested from the patient's knee, finger, ear, or splintered nose. The cells are then mixed with a biopolymer made from alginic acid to give the future organ a shape and the strength to be printed in the form of the patient's nose. This mixture of the patient's cartilage cells and the biopolymer is then placed into a bioprinter to print the artificial nose based on the 3D image scan. Subsequently, the artificial nose is transplanted into the patient; the biopolymer will degrade over time as the cartilage cells multiply and grow to shape the new nose. Hence, any facially disfigured individual with a broken nose may rely on bioprinting in the future and stem cell regeneration to obtain a new nose. For people with malformed noses, this new technology is promising, though animal and human trials will need to be conducted first to ensure safety.

Skin replacement, too, has progressed with the advent of bioprinting. A particular portion of skin, which is to be replaced, is scanned using Computer Aided Design (CAD) software to identify the skin's architecture. Next, a patient's cells, such as keratinocytes, fibroblasts and melanocytes, are isolated from the patient through a biopsy. These cells are then multiplied through in vitro culturing to obtain the required cell density and a sufficient amount for the skin replacement. Subsequently, the multiplied cells are mixed with a suitable polymer, such as alignate, to strengthen the texture of the cells and placed into a bioprinter. According to Augustine [44], mesenchymal stem cells may also be obtained from a patient and "differentiated into various skin layers after printing" (p. 81). The replacement skin is then printed and left to mature under in vitro conditions. Lastly, the skin construct is implanted into the affected area of a patient. The development of skin bioprinting has progressed with the creation of a mobile bioprinter by Wake Forest Institute for Regenerative Medicine to print skin in times of combat to be used on injured soldiers who have suffered burns [45].

Bioprinting in the future holds more possibilities for disabled people with heart or kidney problems, whose normal daily activities are affected by weakness, and who currently have to depend 
on mechanical hearts or kidney transplants from donors. Bioprinting research is underway to create kidneys and hearts; however, because of the problem of vascularisation, which is critical to funnelling blood and oxygen into these organs, such bioprinted organs are not expected to be available for several decades [3] (p. 574).

In summary, bioprinting, which is part of IR 4.0, has the potential to create new tissues, and organs that may improve the well-being of those with disabilities stemming from congenital deformities, from accidents, or from the aging process.

\subsection{The Development of Bioprinting in Malaysia}

In Malaysia, bioprinting is gaining in popularity within the country's research institutions, universities, and industries. A researcher in MediTeg at the Universiti Teknologi Malaysia is in the process of developing a blood vessel meant for coronary heart surgery [46]. A facility to bioprint skin at MediTeg has been developed for skin replacement meant for burns and pimple scars [46]. Researchers at the University of Malaya (UM) have evaluated the suitability of fibrin-gelatin, a hydrogel, for bioprinting skin [47]. At the Universiti Tun Hussein Onn Malaysia (UTHM) in Johor, the Biosensor and Bioengineering Laboratory, MiNT-SRC, recently embarked on a project to build their own 3D bioprinter [48].

Furthermore, foreign companies offering 3D printing and bioprinting services have made their mark in Malaysia. A doctor at the Pantai Medical Hospital in Kuala Lumpur collaborated with Materialise to utilise virtual surgical planning and 3D-printed surgical guides to facilitate the repositioning of a patient's fractured arm bone [49] (p. 2). A computer tomography (CT) scan of the patient's arm was first conducted to provide digital data for a virtual 3D reconstruction of the patient's bone [49]. Stratasys introduced 3D printing technology to the Centre for Biomedical and Technology Integration (CBMTI), UM, which can create custom biomodels for research and surgical training [50] (p. 1). Materialise also enabled a specialist at the Tuanku Mukhris Hospital, National University of Malaysia (UKM), to make use of its virtual surgical planning and 3D-printed surgical guide technology to enable the reconstruction of a patient's skull following a car accident [51] (p. 3). The transplant into a female patient with a broken skull of a custom-made, 3D-printed, titanium implant, identical to a real bone was the first procedure of its kind in Malaysia [51] (p. 3). The magnetic resonance imaging (MRI) and CT scan of the patient's skull, as well as the utilisation of computer-aided design-specialised 3D software, helped to produce the titanium implant for her skull [51] (p. 3). At Universiti Putra Malaysia in Selangor, scientists have created a customised anatomical model known as Medical Grade 3D Print, which will enable doctors to practice surgery with precision on a model of a human organ with the same texture and structure as a genuine organ, prior to conducting a real operation [52]. An MRI or CT scan of a patient's organ is used to create an identical model, which is then turned into a mould.

Whilst the field is progressing, bioprinting is still in its infancy in Malaysia. If it is to make an impact in Malaysia, more grants are needed for local scientists in the area of biomedicine to spur further research. Local and international collaboration among research institutions, public universities, and private universities is needed, as such cooperation optimises financial resources, equipment usage, and human resources specialisation in biomedicine. In line with the CRPD's call for the transfer of technology, international collaboration can aid in the dissemination of cutting-edge knowledge to local Malaysian researchers. In East Asia, South Korea, which has the leading edge in 3D printing, has been identified by Malaysia as a potential source of technology transfer [53].

Tan and Ong [54] highlighted that biomedical engineers in Malaysia should consider how they can produce devices that can help disabled people regain their bodily functions. Bioprinting, which is a subset of biomedicine, has been instrumental in a number of medical breakthroughs, such as the creation of tissues, and the bioprinting of complex organs may become available in the distant future. These developments in bioprinting would be beneficial for people with disabilities in Malaysia. A major obstacle is that the Ministry of Energy, Science, Technology, Environment and Climate Change 
(MESTECC) must generate awareness among Malaysian researchers that any devices pertaining to bioprinting research should meet the needs of those with disabilities. Even the Academy of Sciences Malaysia (ASM) should update its mindset to include the needs of those with disabilities in addition to the needs of elderly people because this government body advises the MESTECC on current technological trends that Malaysia should adopt for the good of Malaysian society. It is also crucial for the Ministry of Women, Family and Community Development in Malaysia, which is in charge of disability-related issues, to work together with MESTECC and the ASM to promote the roles of R\&D and new technologies, such as bioprinting, that can medically benefit disabled people.

\subsection{Malaysia's Disabled Population}

In Malaysia, disabled people are defined in Section 2 of the PDA 2008 as "those who have long term physical, mental, intellectual or sensory impairments which in interaction with various barriers may hinder their full and effective participation in society" [5]. Individuals who are disabled in Malaysia are divided into seven categories, namely those with hearing, speech, physical, mental, learning, visual and multiple disabilities.

Registration as a disabled person is voluntary rather than mandatory in Malaysia. In 2015, there were 365,677 individuals registered as disabled, 409,269 individuals in 2016, 453,258 individuals in 2017, 513,519 individuals in 2018 and 549,554 individuals as of June 2019 as in Figure 3 [55-57]. The 513,519 individuals registered in 2018 represent only 1.6\% of people with disabilities, when the WHO's target should be $15 \%$ [55]. Since registering as a disabled individual is voluntary, the statistics provided by Malaysia's Social Welfare Department (SWD) may not represent the actual number of disabled people in the country.

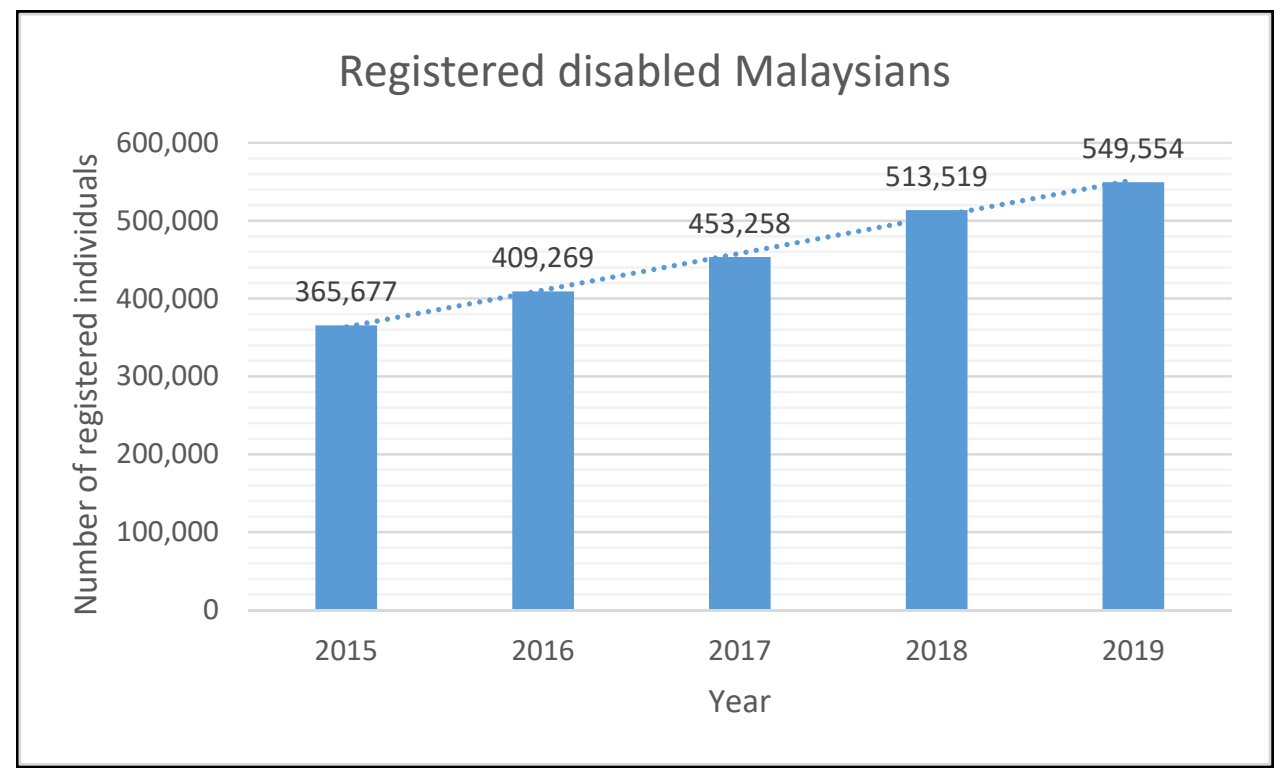

Figure 3. This graph shows the number of registered persons with disabilities in Malaysia from 2015-June, 2019. Source: Social Welfare Department, Malaysia [56], Ong [55] and Asyraf [57].

Based on the 2018 statistics, the breakdown of different types of disability is as follows. Around $7.4 \%$ of individuals registered as disabled have a hearing disability and $0.5 \%$ have a speech disability [58]. Individuals suffering from microtia are categorised as having a hearing disability. Those who suffer from microtia may also have speech impairment and thus fall into the category of multiple disabilities. Overall, $4.7 \%$ of people with disabilities have multiple disabilities, $8.4 \%$ have a mental disability, around $8.9 \%$ are visually impaired, $34.7 \%$ have a physical disability and $35.4 \%$, representing the largest group, have learning disabilities [58]. Physical disability would include individuals suffering from long-term chronic illnesses such as those with kidney failure and needing replacement kidneys [59]. 
Malaysia's Ministry of Health $(\mathrm{MOH})$ also provides assistance to those suffering from chronic heart problems who are regarded as people with disabilities and registered with the SWD [60]. Some of the heart diseases being addressed include coronary artery disease, angioplasty, myocardial infarcation, cardiomyopathy, congenital heart disease and hyperthropic obstructive cardiomyopathy (HOCM) [60].

Bioprinting has the potential to assist the Malaysian population suffering from microtia, characterised by a malformed external ear (pinna), through cosmetic surgery to replace or modify the unsightly ear with one which has been bioprinted. This could certainly improve the physical appearance of a hearing-impaired individual and thus would reduce the instances in which the individual is stared at or considered abnormal. In Malaysia, there has not been a consistent documentation of statistics by the relevant authority concerning individuals suffering from microtia. The $\mathrm{MOH}$ last recorded cases of microtia from 2010-2011 [61]. In 2010, there were six cases of microtia and thirteen in 2011 [61]. One study was conducted on 48 microtia patients at the then Universiti Kebangsaan Malaysia Medical Center (UKMMC) from March, 2012-March, 2013 [62]. This study at UKMMC found that microtia was prevalent among the Malay population with a $0.27 \%$ predominance [62]. Moreover, the study showed that the majority of the affected population had unilateral microtia amounting to $62.5 \%$, with the right ear most affected in $39.6 \%$ of patients [62]. Overall, there has been no large-scale study at the national level to consistently document statistics on microtia cases in Malaysia which would make it easier to gauge the extent to which the Malaysian population is affected by this disability.

With regard to bioprinting kidneys in the longer term, such progress would certainly help Malaysia's physically disabled individuals suffering from long-term kidney failure and needing to undergo dialysis treatment for most of their lives. If researchers do succeed in creating bioprinted kidneys in the future, Malaysia's long-term physically disabled individuals suffering from kidney failure would have a ray of hope that there may be an opportunity to replace their malfunctioning kidneys with bioprinted versions using their own cells [63]. This would certainly prevent any rejection of new kidneys, since a patient's own cells are used. As of June 2019, it was reported that there were 20,000 patients in Malaysia on the waiting list for kidney transplant [64].

The disabled population in Malaysia suffering from heart failure would also be offered hope. If scientists manage to successfully bioprint a heart and keep it alive for long periods of time, then transplantation into a patient may become a viable option, and people with disabilities who need a heart replacement may have a brighter future to look forward to. The risk of heart rejection would be minimised with a bioprinted heart utilising a patient's own cells. A disabled patient would not have to wait for such a long time for a heart donor and would not have to take drugs to prevent rejection of the heart.

According to Malaysia's MOH, burns would come under the category of general disabilities as severe disfigurement can impair an individual physically [65]. In 2018, there were 36,758 cases of fire in Malaysia [66]. There were 397 cases of fire injuries sustained in 2018 [66]. Up to June 2019, there were 207 cases of injuries caused by fire and 49 deaths recorded [67]. Statistics on cases of fire-related injuries were unavailable from the website of the Ministry of Housing and Local Development, Malaysia, for the remaining half of 2019 up to December.

With the prevalence of injuries caused by fire, victims may suffer severe burns which require skin replacement. Bioprinting of skin could, therefore, play a significant part in treatment for this issue by producing new skin for victims using their own cells. By the same token, any person in Malaysia who has suffered from severe burns may have the option of bioprinted skin once this technology has been fully developed. Bioprinted skin may also be useful for victims who have suffered from an acid attack or those who have a severe skin disease requiring skin replacement.

In Malaysia, the prevalence of knee osteoarthritis affects $10 \%-20 \%$ of the elderly population [68] (p. 7). A study conducted by the Community Oriented Program for the Control of Rheumatic Diseases (COPCORD) indicated that out of $64.8 \%$ of joint complaints relating to the knee, more than $50 \%$ were caused by knee osteoarthritis [68] (p. 7). Around $23 \%$ of patients over 55 years of age complained of pains and this increased to $39 \%$ among patients over 67 years old [68] (pp. 7-8). 
Therefore, the bioprinting of living tissue to replace a damaged joint could solve this problem for osteoarthritis sufferers.

While bioprinting may be the panacea to cure the ills of people with disabilities, there is no clear indication of how much the creation of replacement organs, and tissue combined with the price of surgery, may cost. As researchers worldwide are experimenting with different forms of materials for bioprinting, the cost of surgery, replacement organs, and tissue depends on the type of materials and bioprinter used. If Malaysian people with disabilities are to resort to bioprinted organs, and tissue, the costs must be lower than the cost of existing options to make the techniques viable. For instance, knee replacement surgery at a public hospital in Malaysia can cost RM \$10,000-35,000 (USD 2305-8070) while in a private hospital, it costs RM 25,000-45,000 (USD 5764-10,375) [69]. Plastic surgery for an ear currently costs RM $\$ 5204.40-7806.60$ (USD 1200-1800) in Malaysia [70] while reconstructive surgery for a nose costs RM \$6505-17,348 (USD 1500-4000) [71]. The current cost of kidney transplantation for adults in Malaysia is RM $\$ 35,078$ (USD 8609) and RM $\$ 57,287$ (USD 13,209) for a living donor kidney transplant (LKT) as well as a deceased donor kidney transplant [72]. As for children, kidney transplantation can cost RM \$45,473-64,989 (USD 10,485-14,985) [72]. Additionally, Malaysia's National Heart Institute (IJN) has estimated that a heart transplant costs RM \$150,000-300,000 (USD 34,586-69,172) [73] (p. 4).

This subsection has demonstrated how bioprinting may be beneficial for people with disabilities as an option in the future. This is, however, dependent on the cost of these bioprinted organs, tissue, materials and the type of bioprinter being used not superseding the current price of medical surgery in Malaysia. If bioprinting proves too expensive in Malaysia, government intervention may be required to lower the costs or to subsidise the surgery to make it accessible for people with disabilities.

\subsection{The Capacity of Malaysia's Disability Law to Address Research and Development (RED) and New Technologies}

This section will evaluate whether Malaysia's PDA 2008 has any related provision that could address the introduction of new technologies to enable the utilisation of bioprinting in producing devices for those with disabilities. Islam [17] (p. 175) as well as Osman and Diah [74], in their research on ICT among those with disabilities in Malaysia, found poor implementation of ICT among this marginalised group in terms of the infrastructure provided and the unnecessarily high costs. In the PDA 2008, Article 30(1)-(2) requires that people with disabilities be provided with ICT in accessible formats [5]. This raises a salient issue: whether Article 30 in the PDA 2008 is the only provision covering technology.

Upon further observation, it would seem that Article 33(3) of the PDA 2008 [5] requires that the National Council for Persons with Disabilities elected to oversee the issue of disabilities within Malaysia, private healthcare service providers, and NGOs must promote the availability, knowledge, and use of assistive devices and technologies. The term "technologies" is not defined in the PDA 2008. However, Article 9(1) (k) in the PDA 2008 [5] promotes research that the Ministry of Women, Family and Community Development can utilise to encourage scientists in Malaysia to use bioprinting with the aim of producing tissues, and replacement organs for those with disabilities. The Ministry of Women, Family and Community Development should thus solicit the assistance of the MESTECC to realise this goal. In so doing, Malaysia would be fulfilling its state obligation on the right to science, since adopting the necessary legal and policy framework to spur R\&D is an integral part of the measures to realise this right, as indicated in the Venice Statement [35] (p. 17).

In addition to the above, it should be feasible to obtain the assistance of the ASM in making bioprinting a priority. The ASM promotes regenerative medicine for the purpose of producing useful tissues and organs, but this advocacy only pertains to the use regenerative medicine for the elderly [75] (p. 91). In the Advisory Report on Stem Cells: Ageing and Regenerative Medicines, which the ASM produced, the term "disabled" is restricted to the elderly and fails to acknowledge those who have disabilities due to other issues [76]. The ASM's advisors should broaden this definition to include those with disabilities, either from birth or who have incurred them later in life due to accidents, injuries, 
or diseases. In this sense, the Ministry of Women, Family and Community Development must urge the ASM to change its concept of the term "disabled". The ASM should also directly promote bioprinting together with stem cell research, as both contribute to regenerative medicine.

While Article 9(1) (k) of the PDA 2008 [5] promotes research, the right of disabled people to be informed about the availability of new technologies, such as bioprinting, is embedded in Article 33(3). The National Council for Persons with Disabilities, healthcare service providers, and related NGOs, if they are aware of the medical benefits of bioprinting, have a duty to inform those with disabilities of any options which are available to them so that these people can make informed decisions about implants which may be useful to them. Malaysia should also endeavour to encourage bioprinting among its scientists through the Malaysian Plan of Action for People with Disabilities 2016-2022 [77]. Core Strategic 8 of this plan encourages R\&D for those with disabilities and conveys the outcomes of research [77]. Moreover, the Universiti Sultan Zainal Abidin (UniSZA) in Terengganu has been designated as the national centre of design for disability in Malaysia [78], and this measure demonstrates that the $R \& D$ component in producing products for those with disabilities is starting to gain more prominence in Malaysia. The centre at UniSZA should look into the potential of bioprinting and should encourage more Malaysian scientists to embark on research that produces tissues and replacement organs for people with disabilities.

Hence, it is obvious that the PDA 2008 addresses the right to science because it contains a provision encouraging $R \& D$, the promotion of technologies for those with disabilities, and these individuals' right to knowledge about new technologies. All of the provisions mentioned above offer an opportunity to promote bioprinting for the betterment of those with disabilities. The analysis also demonstrates that these provisions would fulfil Article 4(1) (g)-(h) of the CRPD, which Malaysia ratified on 19 July 2010 [79].

\section{Discussion and Conclusions}

This study began by aiming to identify the relevant provisions within the CRPD and Malaysia's PDA 2008 to support bioprinting, which could lighten the hardship of those suffering from disabilities regardless of the cause or category of disability. The travaux préparatoires of the CRPD revealed that the term "new technologies" within Article 4(1) (g)-(h) of the CRPD could extend to cover other technology besides ICT and AT; past documentation indicated that the said term should cover biomedicine, as proposed by Chile. As bioprinting is part of biomedicine, these provisions facilitate the introduction of bioprinting technology to medically emancipate the lives of those with disabilities. This study also showed that Article 4(1) (g)-(h) of the CRPD indirectly covers the right to science through features similar to those found within Article 27 of the UDHR and Article 15(1) (b) of the ICESCR, as highlighted by Bryden and Gran [9]. This observation seems to confirm Cascio, Weiss, and Racine's [8] earlier claims, as indicated in the literature review, that the identified provisions within the CRPD address the right to science, albeit indirectly. The findings from this study are significant because they imply that any new technology, regardless of those from IR 4.0, can be used for the benefit of people with disabilities; the term "disability" has purposely been left undefined, and this loophole allows for the inclusion of other technologies in the future.

Regarding the Malaysia PDA 2008, a few provisions would seem to promote the right to science. Article 33(3) of the PDA 2008 requires the relevant parties to make available and impart knowledge about the use of assistive devices and technologies to those with disabilities [5]. Moreover, Article 9(1) (k) of the PDA 2008 [5] also requires the National Council for Persons with Disabilities to promote research relevant to the needs of those with disabilities. This article implies that Malaysia's PDA 2008 already meets the requirements of Article 4(1) (g)-(h) of the CRPD. The sole problem is miscommunication between the Ministry of Women, Family and Community Development, MESTECC, and the ASM, as none of these entities are taking sufficient action to create awareness and promote the R\&D of new technologies, such as bioprinting, among researchers in Malaysia that could contribute to the medical needs of people with disabilities. Therefore, the relevant ministries and ASM must rectify 
this situation by improving communication, delving deeply into how bioprinting can serve the needs of those with disabilities, and awarding research grants to scientists to develop medical devices for the needs of the marginalised in Malaysian society. Awareness that Article 9(1) (k) and Article 33(3) of the PDA 2008 [5] promote the right to science among both policymakers and the public at large is also significant in terms of pressuring those responsible to ensure that financial contributions, human resources, technological transfer, and accessibility all focus on delivering this right to people with disabilities. This step will enable Malaysia to be a just society, sensitive to the medical needs of people with disabilities in permitting these individuals access to bioprinted devices regardless of the cost.

Funding: This research was partially funded by the National University of Malaysia (UKM), grant number GGPM-2017-117.

Acknowledgments: The author wishes to thank the anonymous reviewers for their constructive comments.

Conflicts of Interest: The author hereby declares that no conflict of interest exists.

\section{References}

1. Guillemot, F.; Mironov, V.; Nakamura, M. Bioprinting is Coming of Age: Report from the International Conference on Bioprinting and Biofabrication in Bordeaux (3B'09). Biofabrication 2010, 2, 010201. [CrossRef] [PubMed]

2. Mori, A.D.; Fernandez, M.P.; Blunn, G.; Tozzi, G.; Roldo, M. 3D Printing and Electrospinning of Composite Hydrogels for Cartilage and Bone Tissue Engineering. Polymers 2018, 10, 285.

3. Bauermeister, A.J.; Zuriarrain, A.; Newman, M.I. Three-Dimensional Printing in Plastic and Reconstructive Surgery: A Systematic Review. Ann. Plast. Surg. 2016, 77, 569-576. [CrossRef] [PubMed]

4. Convention on the Rights of Persons with Disabilities. Available online: https://www.un.org/disabilities/ documents/convention/convoptprot-e.pdf (accessed on 3 March 2020).

5. Persons with Disabilities Act 2008 (Act 685), Malaysia. Available online: http://www.ilo.org/dyn/natlex/docs/ ELECTRONIC/86297/117930/F139356912/MYS86297.pdf (accessed on 3 March 2020).

6. Consortium of Social Science Associations (COSSA). Science and Human Rights Coalition Focuses on Disability Rights. COSSA Wash. Update 2014, 33, 1-3.

7. Wolbring, G. 'Therapeutic', Enhancement Enabling, Assistive Devices and the UN Convention on the Rights of Persons with Disabilities: A Missing Lens in the Enhancement Regulation Discourse. J. Int. Biotechnol. Law 2009, 6, 193-206. [CrossRef]

8. Cascio, M.A.; Weiss, J.E.; Racine, E. Empowerment in Decision-Making for Autistic People in Research. Disabil. Soc. 2020, 35, 1-43. [CrossRef]

9. Bryden, A.; Gran, B. Human Rights, Technology, and Disabilities: The Right to Benefit from Scientific Progress. In Proceedings of the XIX ISA World Congress on Sociology, Toronto, ON, Canada, 15-21 July 2018; International Sociological Association (ISA): Madrid, Spain, 2018; p. 168.

10. International Covenant on Economic, Social and Cultural Rights. Available online: https://reaties.un.org/ doc/Treaties/1976/01/19760103\%2009-57\%20PM/Ch_IV_03.pdf (accessed on 3 March 2020).

11. United Nations General Assembly (UNGA). Report of the Special Rapporteur in the Field of Cultural Rights, Farida Shaheed: The Right to Enjoy the Benefits of Scientific Progress and Its Applications, A/HRC/20/26; UNGA: New York, NY, USA, 2012.

12. Abegaz, S.T. Marching for 3D Printing: Its Potential to Promoting Access to Healthcare in Africa. In Reflections on Bioethics; Morales-Gonzalez, J.A., Nájera, E.A., Eds.; IntechOpen: London, UK, 2018; pp. 123-135.

13. Gould, M.; Leblois, A.; Bianchi, F.C.; Montenegro, V. Convention on the Rights of Persons with Disabilities, Assistive Technology and Information and Communication Technology Requirements: Where Do We Stand on Implementation? Disabil. Rehabil. Assist. Technol. 2015, 10, 295-300. [CrossRef]

14. Desmond, D.; Layton, N.; Bentley, J.; Boot, F.H.; Borg, J.; Dhungana, B.M.; Gallagher, P.; Gitlow, L.; Gowran, R.J.; Groce, N.; et al. Assistive Technology and People: A Position Paper from the First Global Research, Innovation and Education on Assistive Technology (GREAT) Summit. Disabil. Rehabil. Assist. Technol. 2018, 13, 437-444. [CrossRef]

15. Doyle-Kent, M.; Fanning, M.; O’Brien, D.; Kopacek, P. Cost Oriented Robotic Arm Optimised to Aid Independence. IFAC-PapersOnLine 2019, 52, 125-130. [CrossRef] 
16. Tah, I.H.M. A Need for Remedial Provision to Protect Persons with Disabilities in Malaysia. Int. J. Bus. Econ. Law 2013, 3, 1-4.

17. Islam, M.R. Rights of the People with Disabilities and Social Exclusion in Malaysia. Int. J. Soc. Sci. Humanit. 2015, 5, 171-177. [CrossRef]

18. Tah, I.H.M.; Mokhtar, K.A. Transforming Disability Studies through Legal Perspectives in Malaysia. J. Appl. Environ. Biol. Sci. 2017, 5, 51-55.

19. Talib, R.I.A.; Sunar, M.S.; Mohamed, R. Digital Society and Economy for People with Disabilities in Industry 4.0: Malaysia Perspectives. EAI Endorsed Trans. Creat. Technol. 2019, 6, 1-9. [CrossRef]

20. Universal Declaration of Human Rights. Available online: https://www.ohchr.org/EN/UDHR/Documents/ UDHR_Translations/eng.pdf (accessed on 3 March 2020).

21. Merezhko, O. Legal Hermeneutics and Methodology of Law. Eur. Polit. Law Discourse 2014, 1, 4-10.

22. Cowney, F.; Bradney, A. Socio-legal Studies: A Challenge to the Doctrinal Approach. In Research Methods in Law; Watkins, D., Burton, M., Eds.; Routledge: New York, NY, USA, 2013; pp. 34-54.

23. United Nations Department of Economic and Social Affairs (UNDESA). Convention on the Rights of Persons with Disabilities (CRPD): Entry into Force. Available online: https://www.un.org/development/ desa/disabilities/convention-on-the-rights-of-persons-with-disabilities/entry-into-force.html (accessed on 3 March 2020).

24. United Nations Department of Economic and Social Affairs (UNDESA). Convention on the Rights of Persons with Disabilities (CRPD): Ratifications/Accessions, Signatories. Available online: https://www.un. org/development/desa/disabilities/convention-on-the-rights-of-persons-with-disabilities.html (accessed on 3 March 2020).

25. United Nations General Assembly (UNGA). Letter Dated 7 October 2005 from the Chairman to All Members of the Committee, A/AC.265/2006/1; UNGA: New York, NY, USA, 2005.

26. Kanter, A.S. The United Nations Convention on the Rights of Persons with Disabilities and its Implications for the Rights of Elderly People under International Law. Ga. State Univ. Law Rev. 2009, 25, 527-573.

27. Kayess, R.; Fogarty, B. The Rights and Dignity of Persons with Disabilities: A United Nations Convention. Altern. Law J. 2007, 32, 22-30. [CrossRef]

28. United Nations Department of Economic and Social Affairs (UNDESA). Compilation of Proposals for a Comprehensive and Integral International Convention to Promote and Protect the Rights and Dignity of Persons with Disabilities. Ad Hoc Committee on a Comprehensive and Integral International Convention on Protection and Promotion of the Rights and Dignity of Persons with Disabilities; United Nations: New York, NY, USA, 2003.

29. United Nations Department of Economic and Social Affairs (UNDESA). Bangkok Draft: Proposed Elements of a Comprehensive and Integral International Convention to Promote and Protect the Rights of Persons with Disabilities. Regional Workshop towards a Comprehensive and Integral International Convention on Protection and Promotion of the Rights and Dignity of Persons with Disabilities; Ad Hoc Committee on an International Convention, United Nations Department of Economic and Social Affairs (UNDESA); United Nations: New York, NY, USA, 2003.

30. United Nations Department of Economic and Social Affairs (UNDESA). Compilation of Proposals for Elements of a Convention; Working Group of the Ad Hoc Committee on a Comprehensive and Integral International Convention on Protection and Promotion of the Rights and Dignity of Persons with Disabilities; United Nations: New York, NY, USA, 2004.

31. United Nations General Assembly (UNGA). Report of the Third Session of the Ad Hoc Committee on a Comprehensive and Integral International Convention on the Protection and Promotion of the Rights and Dignity of Persons with Disabilities, A/AC.265/2004/5; UNGA: New York, NY, USA, 2004.

32. United Nations General Assembly (UNGA). Report of the Ad Hoc Committee on a Comprehensive and Integral International Convention on the Protection and Promotion of the Rights and Dignity of Persons with Disabilities on Its Seventh Session, A/AC.265/2006/2; UNGA: New York, NY, USA, 2006.

33. Borg, J.; Lindström, A.; Larsson, S. Assistive Technology in Developing Countries: National and International Responsibilities to Implement the Convention on the Rights of Persons with Disabilities. Lancet 2009, 374, 1863-1865. [CrossRef]

34. Scanlon, M.L.; MacNaughton, G.; Sprague, C. Neglected Population, Neglected Right: Children Living with HIV and the Right to Science. Heal. Hum. Rights J. 2017, 19, 169-180. 
35. United Nations Educational, Scientific and Cultural Organization (UNESCO). The Right to Enjoy the Benefits of Scientific Progress and its Applications; United Nations Educational, Scientific and Cultural Organization: Paris, France, 2009.

36. World Health Organization (WHO). Medical Device-Full Definition. Available online: https://www.who.int/ medical_devices/full_deffinition/en/ (accessed on 3 March 2020).

37. Case of Artavia Murillo Et Al. (“In Vitro Fertilization”) v. Costa Rica. Judgment of 28 November 2012, Inter-American Court of Human Rights. Available online: https://www.corteidh.or.cr/docs/casos/articulos/ seriec_257_ing.pdf (accessed on 31 March 2020).

38. López, Glenda y otros c. Instituto Venezolano de los Seguros Sociales (IVSS) s/ Acción de Amparo. Expediente 00-1343. Sentencia $N^{\circ}$ 487. 1997. Available online: https://www.globalhealthrights.org/wp-content/uploads/ 2013/08/Lopez-v.-IVSS-English-Translation.pdf (accessed on 31 March 2020).

39. Lovászy, L.G. Innovation has Changed the Meaning of (Re) Habilitation. EuroScientist. Available online: http://21ax0w3am0j23cz0qd1q1n3u-wpengine.netdna-ssl.com/wp-content/uploads/2016/ 02/Innovation-has-chnaged-the-meaning-of-rehabilityation-FINAL.pdf (accessed on 3 March 2020).

40. Zhou, G.; Jiang, H.; Yin, Z.; Liu, Y.; Zhang, Q.; Pan, B.; Zhou, J.; Zhou, X.; Sun, H. In Vitro Regeneration of Patient-Specific Ear-Shaped Cartilage and Its First Clinical Application for Auricular Reconstruction. EBioMedicine 2018, 28, 287-302. [CrossRef]

41. Freier, A. Researchers 3D Bioprint the First Ears Made from Children's Own Cells. Available online: https://all3dp.com/researchers-3d-bioprint-first-ears-made-childens-cells/ (accessed on 25 February 2020).

42. Horizon. 3D-Printed Living Tissues Could Spell the End of Arthritis. Horizon: The EU Research \& Innovation Magazine. Available online: https://horizon-magazine.eu/article/3d-printed-living-tissues-could-spell-endarthritis.html (accessed on 3 March 2020).

43. Schlaefli, S. Nose Made by Bioprinters. Globe Magazine. Available online: https:/ethz.ch/en/news-andevents/eth-news/news/2015/03/nose-made-by-bioprinters.html (accessed on 3 March 2020).

44. Augustine, R. Skin Bioprinting: A Novel Approach for Creating Artificial Skin from Synthetic and Natural Building Blocks. Prog. Biomater. 2018, 7,77-92. [CrossRef]

45. Wake Forest Baptist Medical Center. Mobile Bedside Bioprinter Can Heal Wounds. Science Daily. 28 February 2019. Available online: https://www.sciencedaily.com/releases/2019/02/190228134229.htm (accessed on 4 May 2020).

46. Supriyanto, I.E. Cardiovascular and Biomedical Research at Universiti Teknologi Malaysia. Available online: https://mrc.ukri.org/documents/pdf/universiti-teknologi-malaysia/ (accessed on 28 January 2019).

47. Hakam, M.S.; Imani, R.; Abolfathi, N.; Fakhrzadeh, H.; Sharifi, A.M. Evaluation of Fibrin-Gelatin Hydrogel as Biopaper for Application in Skin Bioprinting: An In-Vitro Study. Biomed. Mater. Eng. 2016, 27, 669-682. [CrossRef] [PubMed]

48. Kian, S.T.; Low, E.; Ramilan, M.F.; Rahim, R.A.; Saim, H.; Zakaria, W.N.W.; Khialdin, S.M.; Isa, H.; Chin, F.S. A Development of a 3D Bio-Printer. J. Tomogr. Syst. Sens. Appl. 2019, 2, 1-10.

49. Park, R. 3D Printed Surgical Guides Make Their Malaysian Debut. 3D Printing Industry. 20 June 2013. Available online: https://3dprintingindustry.com/news/3d-printed-surgical-guides-make-their-malaysiandebut-13222/ (accessed on 15 June 2017).

50. Kumar, A. Malaysian Biomedical Centre's “Major Breakthrough" Using Stratasys 3D Printing. CIO Asia. 14 November 2013. Available online: https:/www.cio-asia.com/tech/imaging-and-printing/malaysianbiomedical-centres-major-breakthrough-using-stratasys-3d-printing/ (accessed on 16 June 2017).

51. Lee, M.L. 3D Printing May Save Your Life If You Need Risky Surgery. Star Online. 25 October 2015. Available online: https:/www.star2.com/health/wellness/2015/10/25/3d-printing-may-save-your-life-if-youneed-risky-surgery/ (accessed on 19 January 2017).

52. Muda, A.S.; Mohammed, Y. Medical Grade 3D Print (MeG3rD). Available online: https://sciencepark.upm. edu.my/article/medical_grade_3d_print_meg3rd-40793?L=en (accessed on 14 March 2020).

53. Lee, J. "Future of Malaysia, Korea Lies in ASEAN": International Trade Minister. Korea Herald. 24 October 2018. Available online: http://www.koreaherald.com/view.php?ud=20181022000796 (accessed on 26 December 2018).

54. Tan, L.F.; Ong, C.W. Big Need for Biomed Engineers. Star Online. 26 July 2015. Available online: https://www.thestar.com.my/news/education/2015/07/26/big-need-for-biomed-engineers (accessed on 2 February 2020). 
55. Ong, H.S. Wan Azizah: Govt Committed to Welfare of OKU Community. Star Online. 13 April 2019. Available online: https://www.thestar.com.my/news/nation/2019/04/13/wan-azizah-govt-committed-to-welfare-ofoku-community/ (accessed on 14 May 2020).

56. Social Welfare Department, Malaysia. Statistical Registration of People with Disabilities According to State. 2018. Available online: https://ydata.iyres.gov.my/iyresbankdataV2/www/index.php?r=pub/home/ readcontent4\&id $=110$ (accessed on 10 May 2020).

57. Asyraf, F. Disabled Children Not Registered with Social Welfare Dept Because Parents Embarrassed. Malaysiakini. 22 September 2019. Available online: https://www.malaysiakini.com/news/492865 (accessed on 15 May 2020).

58. Ministry of Human Resources, Malaysia. Percentage of Registration of Persons with Disabilities (PWD) by Category of Disabilities Malaysia 2018. Available online: https://www.myforesight.my/2019/06/26/disabilityinclusion/ (accessed on 4 May 2020).

59. Social Welfare Department, Malaysia. Information on Registration for People with Disabilities and Disabled Category; Social Welfare Department: Putrajaya, Malaysia, 2019.

60. Ministry of Health, Malaysia. Assistance for Heart Disease's Patients. Available online: http://www.myhealth. gov.my/en/assistance-heart-diseases-patient/ (accessed on 14 May 2020).

61. Ministry of Health, Malaysia. The Annual Report National ORL Registry: Hearing and Otology Related Disease/Cochlear Implant; Ministry of Health, Malaysia: Kuala Lumpur, Malaysia, 2013; ISSN 2289-4379.

62. Hassan, E.; Goh, B.S. The Prevalence and Characteristics of Microtia: A Cross Sectional Study in Universiti Kebangsaan Malaysia Medical Center. In Proceedings of the MSOHNS Annual Scientific Meeting \& 9th Malaysia-Singapore Joint ENT Meeting 2014, Genting Highlands, Malaysia, 20 April 2014; Malaysian Society of Otorhinolaryngologists Head \& Neck Surgeons (MSO-HNS): Kuala Lumpur, Malaysia, 2014; p. 15.

63. Majid, M.A. Combating Malaysia's Involvement in Worldwide Organ Trafficking by Tapping into the Potential of Bioprinting. Glob. J. Bus. Soc. Sci. Rev. 2019, 7, 61-74. [CrossRef]

64. Hassandarvish, M. On Dialysis for Nine Years, KL Man Counts Himself Lucky to Receive Kidney from Brother. Malay Mail Online. 28 November 2019. Available online: https://www.malaymail.com/news/life/ 2019/11/28/on-dialysis-for-nine-years-kl-man-counts-himself-lucky-to-receive-kidney-fr/1814196 (accessed on 4 May 2020).

65. Ministry of Health, Malaysia. General Disabilities. Available online: http://www.myhealth.gov.my/en/ general-disabilities/ (accessed on 14 May 2020).

66. Fire and Rescue Department of Malaysia. Death and Injury Statistics from Fire. 2018. Available online: http://www.data.gov.my/data/dataset/6e4096cf-8e08-4b47-94ed-21bb312b5149/resource/6fe561284f19-4036-918d-642d23869c3c/download/statistik-kematian-dan-kecederaan-akibat-kebakaran-2018.xlsx (accessed on 6 May 2020).

67. Ministry of Housing and Local Government, Malaysia. KPKT Selected Statistics Until 30th June 2019; Ministry of Housing and Local Government: Putrajaya, Malaysia, 2019.

68. Foo, C.N.; Arumugam, M.; Rampal, L.; Munn, S.L.; Sidik, S.M.; Osman, Z.J. Knee Pain and Functional Disability of Knee Osteoarthritis Patients Seen at Malaysian Government Hospitals. Malays. J. Med. Health Sci. 2017, 13, 7-15.

69. Ringgit Plus.com. Ringgit Plus Team Price Difference between a Government vs Private Hospital in Malaysia. Available online: https://ringgitplus.com/en/blog/insurance/government-and-private-hospitals-in-malaysiahow-much-do-they-really-cost.html (accessed on 10 May 2020).

70. Health Tourism.com. Ear Plastic Surgery in Malaysia. Available online: https://www.health-tourism.com/ ear-plastic-surgery/malaysia/ (accessed on 6 May 2020).

71. UniMed Travels. Rhinoplasty in Malaysia. Available online: http://www.unimedtravels.com/rhinoplasty/ malaysia (accessed on 6 May 2020).

72. Sun Daily. There Are 7055 New Patients Every Year, Says Report. Sun Daily. 5 September 2016. Available online: https://www.thesundaily.my/archive/1960044-ISARCH392427 (accessed on 10 May 2020).

73. Kamaruddin, S.P. Normothermic Donor Heart Perfusion Device, TechScan 003/2017; Ministry of Health: Putrajaya, Malaysia, 2017.

74. Osman, O.M.; Diah, N.M. Empowering People with Disabilities (PWDs) via Information Communication Technology (ICT): The Case of Malaysia. Int. J. Stud. Child. Women Elder. Disabl. 2017, 2, 86-93. 
75. Academy of Sciences Malaysia. Science E Technology Foresight Malaysia 2050; Academy of Sciences Malaysia: Kuala Lumpur, Malaysia, 2017.

76. Academy of Sciences Malaysia. Advisory Report on Stem Cells Ageing and Regenerative Medicine. Kuala Lumpur, Malaysia. 2013. Available online: https://www.akademisains.gov.my/asmpub/?smd_process_ download=1\&download_id=210 (accessed on 3 March 2020).

77. Rahim, A.A.; Samad, N.A.A.; Said, I.; Seman, W.; Amin, W.M. Malaysian Plan of Action for People with Disabilities 2016-2022: Way Forward. In Proceedings of the UIA 2017 Seoul World Architects Congress, International Union of Architects (UIA), Seoul, Korea, 3-7 September 2017; International Union of Architects: Seoul, Korea, 2017; pp. 1-6.

78. Ibrahim, M.; Ahmad, M.S.; Abdullah, I.; Omar, M.H.; Ariff, A.F.; Yusoff, S.A.T. UniSZA as the National Centre of Design for Disability in Malaysia. In Proceedings of the IOP Conference Series: Materials Science and Engineering, Kuala Terengganu, Malaysia, 27-28 August 2019; Institute of Physics (IOP): London, UK, 2019; Volume 697, pp. 1-6.

79. Human Rights Commission of Malaysia (SUHAKAM). Persons with Disabilities (PWD). Available online: https://www.suhakam.org.my/areas-of-work/pendidikan/orang-kurang-upaya-oku/ (accessed on 3 March 2020).

(C) 2020 by the author. Licensee MDPI, Basel, Switzerland. This article is an open access article distributed under the terms and conditions of the Creative Commons Attribution (CC BY) license (http://creativecommons.org/licenses/by/4.0/). 